Article

\title{
Tailoring a High Temperature Corrosion Resistant FeNiCrAl for Oxy-Combustion Application by Thermal Spray Coating and HIP
}

\section{Jarkko Metsäjoki 1,*, Maria Oksa ${ }^{1}$, Satu Tuurna ${ }^{2}$, Juha Lagerbom ${ }^{2}$, Jouko Virta ${ }^{1}$, Sanni Yli-Olli ${ }^{1}$ and Tomi Suhonen ${ }^{1}$}

1 VTT Technical Research Centre of Finland Ltd., Espoo 02044, Finland;

E-Mails: maria.oksa@vtt.fi (M.O.); jouko.virta@vtt.fi (J.V.); sanni.yli-olli@vtt.fi (S.Y.-O.); tomi.suhonen@vtt.fi (T.S.)

2 VTT Technical Research Centre of Finland Ltd., Tampere 33101, Finland;

E-Mails: satu.tuurna@vtt.fi (S.T.); juha.lagerbom@vtt.fi (J.L.)

* Author to whom correspondence should be addressed; E-Mail: jarkko.metsajoki@ vtt.fi;

Tel.: +358-40-7377-643.

Academic Editor: Alessandro Lavacchi

Received: 18 September 2015 / Accepted: 13 October 2015 / Published: 16 October 2015

\begin{abstract}
Oxy-fuel combustion combined with CCS (carbon capture and storage) aims to decrease $\mathrm{CO}_{2}$ emissions in energy production using fossil fuels. Oxygen firing changes power plant boiler conditions compared to conventional firing. Higher material temperatures and harsher and more variable environmental conditions cause new degradation processes that are inadequately understood at the moment. In this study, an Fe-Ni-Cr-Al alloy was developed based on thermodynamic simulations. The chosen composition was manufactured as powder by gas atomization. The powder was sieved into two fractions: The finer was used to produce thermal spray coatings by high velocity oxy-fuel (HVOF) and the coarser to manufacture bulk specimens by hot isostatic pressing (HIP). The high temperature corrosion properties of the manufactured FeNiCrAl coating and bulk material were tested in laboratory conditions simulating oxy-combustion. The manufacturing methods and the results of high temperature corrosion performance are presented. The corrosion performance of the coating was on average between the bulk steel references Sanicro 25 and TP347HFG.
\end{abstract}


Keywords: oxy-fuel combustion; powder metallurgy; thermal spray coating; HIP; high temperature; corrosion testing

\section{Introduction}

The energy sector is the largest $\mathrm{CO}_{2}$ emitter globally [1]. One concept to reduce the $\mathrm{CO}_{2}$ emissions originating from the use of fossil fuels in power generation is carbon capture and storage (CCS) [2,3]. Integrated oxy-combustion is considered as one of the most promising technologies to facilitate $\mathrm{CO}_{2}$ capture, because it can be built as a retrofit solution for existing boilers [4]. The oxy-fuel process uses oxygen or oxygen-enriched air to reduce nitrogen in the flue gas and hence increase the $\mathrm{CO}_{2}$ content to facilitate more efficient capture.

Oxy-fuel combustion can be expected to differ from combustion in air by modified distribution of fireside temperatures, much reduced $\mathrm{NO}_{x}$ emissions, increased levels of fireside $\mathrm{CO}_{2}$ and $\mathrm{H}_{2} \mathrm{O}$ with small amounts of $\mathrm{O}_{2}, \mathrm{Ar}, \mathrm{N}_{2}$, and some impurities like $\mathrm{SO}_{2}$ and $\mathrm{Cl}$ [5]. Due to recycling of flue gas in oxy-fired combustion compared to air firing, there is an increased risk of corrosive species enrichment in the flue gas environment [6,7]. These changes in the combustion gas chemistry will also affect the chemistry and formation of deposits. This may increase corrosion of the boiler components that are in contact with the combustion and flue gas environment [8-10]. Coatings are a promising approach to improve corrosion resistance because existing validated structural steels can be used as base material. Coatings can be tailored by composition and structure to give the best surface protection for selected conditions.

Several steels and alloys have been tested in air- and oxy-fuel combustion conditions [11-15]. These include low alloy steels (13CrMo44), ferritic steels (T91, T/P92), austenitic steels (1.4910, Super 304H, TP347HFG, 310N, Sanicro 25 and HR3C), and nickel base alloys (IN617 and IN740). Gagliano et al. [11] tested several candidate materials both in laboratory and field tests in advanced ultra-supercritical conditions. They discovered that a material's resistance to coal ash corrosion is primarily dependent on the chromium content. Alloys containing chromium more than $22 \mathrm{wt} \%$ generally exhibited satisfactory corrosion resistance in laboratory tests. The field study showed that materials containing roughly $25 \mathrm{wt} \%$ chromium exhibited satisfactory resistance, regardless of the fireside corrosion mechanism. Hussain et al. [14] exposed nickel-based thermal spray coatings to corrosion testing simulating fireside corrosion in coal and biomass co-combustion at $650{ }^{\circ} \mathrm{C}$. The best performing coating in the study was $\mathrm{NiCr}$ coating with $46 \mathrm{wt} \%$ of chromium.

In future power plants, oxy-combustion may cause serious corrosion problems to boiler components. Besides testing present available materials, development of new protective materials is essential. Iron-based high chromium content coatings with aluminium addition offer a promising and readily applied solution [16], but require further development and research. This paper presents the development of a new Fe-based alloy from thermodynamical calculations to laboratory testing under simulating oxy-combustion. The Fe-based alloy was tested as a coating manufactured by high velocity oxy-fuel (HVOF) thermal spray process and in a hot isostatic pressed (HIP) bulk form. 


\section{Experimental Section}

The material tailoring for oxy-combustion conditions began with composition selection by thermodynamic calculation. Iron was chosen as the base material, because it is inexpensive, and cost effective material solutions are valued. The thermodynamic calculations were made with the FactSage 6.3 program using the FSsteel database and a custom-compiled database for the environment and deposit. Based on the calculations (Figure 1), Fe-30Ni-14.5Cr-3.5Al, the red dotted line in the Figure 1, was chosen as the material composition. The phase diagram (Figure 1) shows that at temperatures over $675{ }^{\circ} \mathrm{C}$ the structure should be fully austenitic (FCC_A1) with fully soluble alloying elements. The material might have some problems with the formation of a brittle $\sigma$-phase under temperature of $675^{\circ} \mathrm{C}$. Additionally $\mathrm{Al}_{3} \mathrm{Ni}$. precipitates can form under $675^{\circ} \mathrm{C}$.

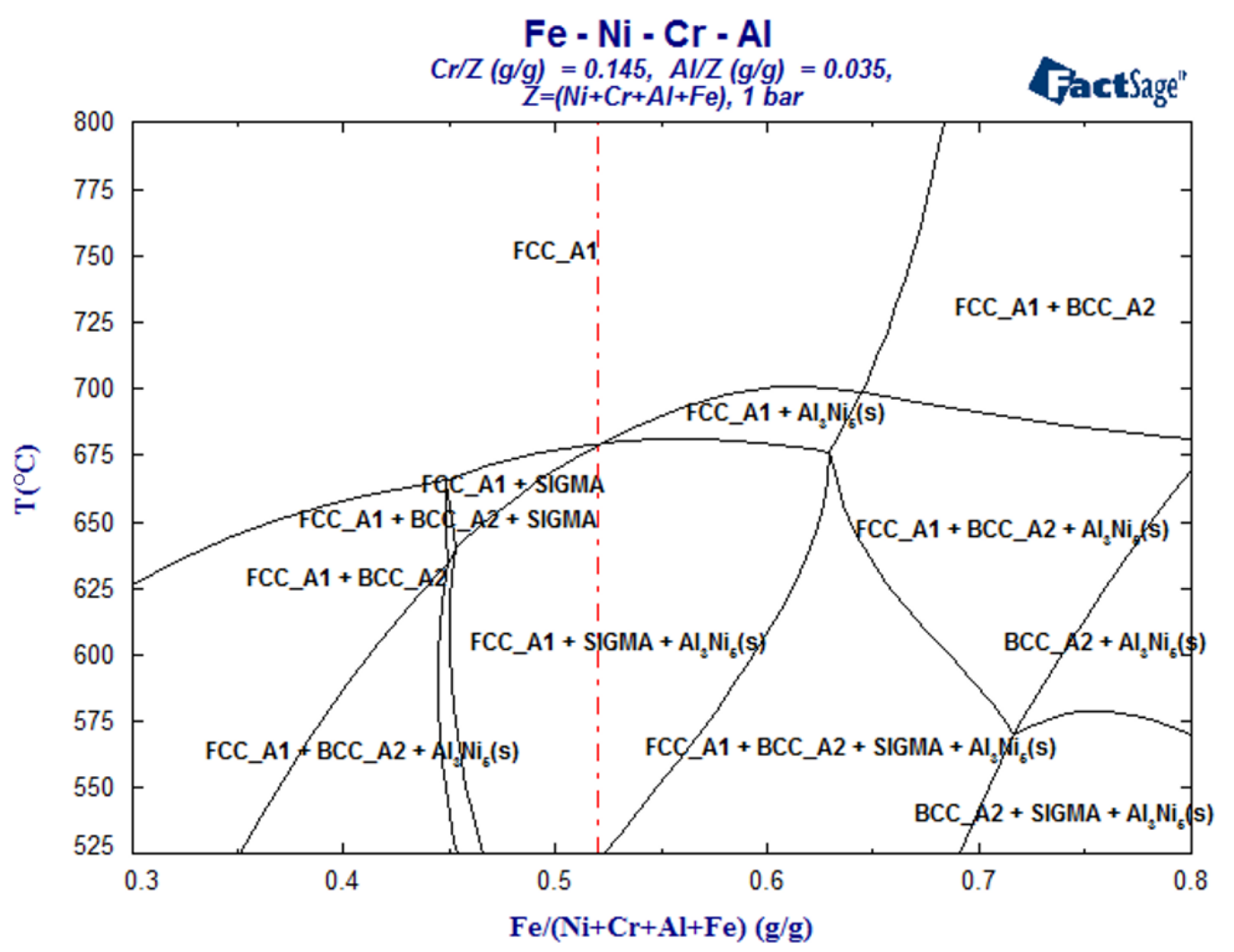

Figure 1. Phase diagram of the designed FeNiCrAl alloy. Selected material composition is marked with a dotted line. FCC_A1 = austenitic and FCC_A2 = ferritic.

Thermodynamic equilibrium calculations were made with a surplus amount of exposure gases $\left(44 \% \mathrm{CO}_{2}-30 \% \mathrm{H}_{2} \mathrm{O}-0.6 \% \mathrm{SO}_{2}-0.2 \% \mathrm{HCl}_{2} \mathrm{~N}_{2}\right)$ and deposit $\left(\mathrm{CaSO}_{4}-0.55\right.$ wt $\left.\% \mathrm{KCl}\right)$. The results are shown in Figure 2, where it can be seen that at $650{ }^{\circ} \mathrm{C}$, the equilibrium favors solid $\mathrm{FeCr}_{2} \mathrm{O}_{4}$ formation along with smaller amounts of $\mathrm{FeO}, \mathrm{FeS}$ and $\mathrm{FeAl}_{2} \mathrm{O}_{4}$ on top of $\mathrm{Fe}$ and $\mathrm{Ni}$, which have high stabilities according to the calculation. The salt and gas would react to form solid $\mathrm{CaCO}_{3}$. Moving to $720{ }^{\circ} \mathrm{C}$ solid $\mathrm{FeO}$ is increasingly preferred while solid $\mathrm{FeS}$ is not. Solid $\mathrm{CaAl}_{2} \mathrm{O}_{4}$ should be formed instead of $\mathrm{FeAl}_{2} \mathrm{O}_{4}$ and solid $\mathrm{CaS}$ instead of $\mathrm{CaCO}_{3}$. 


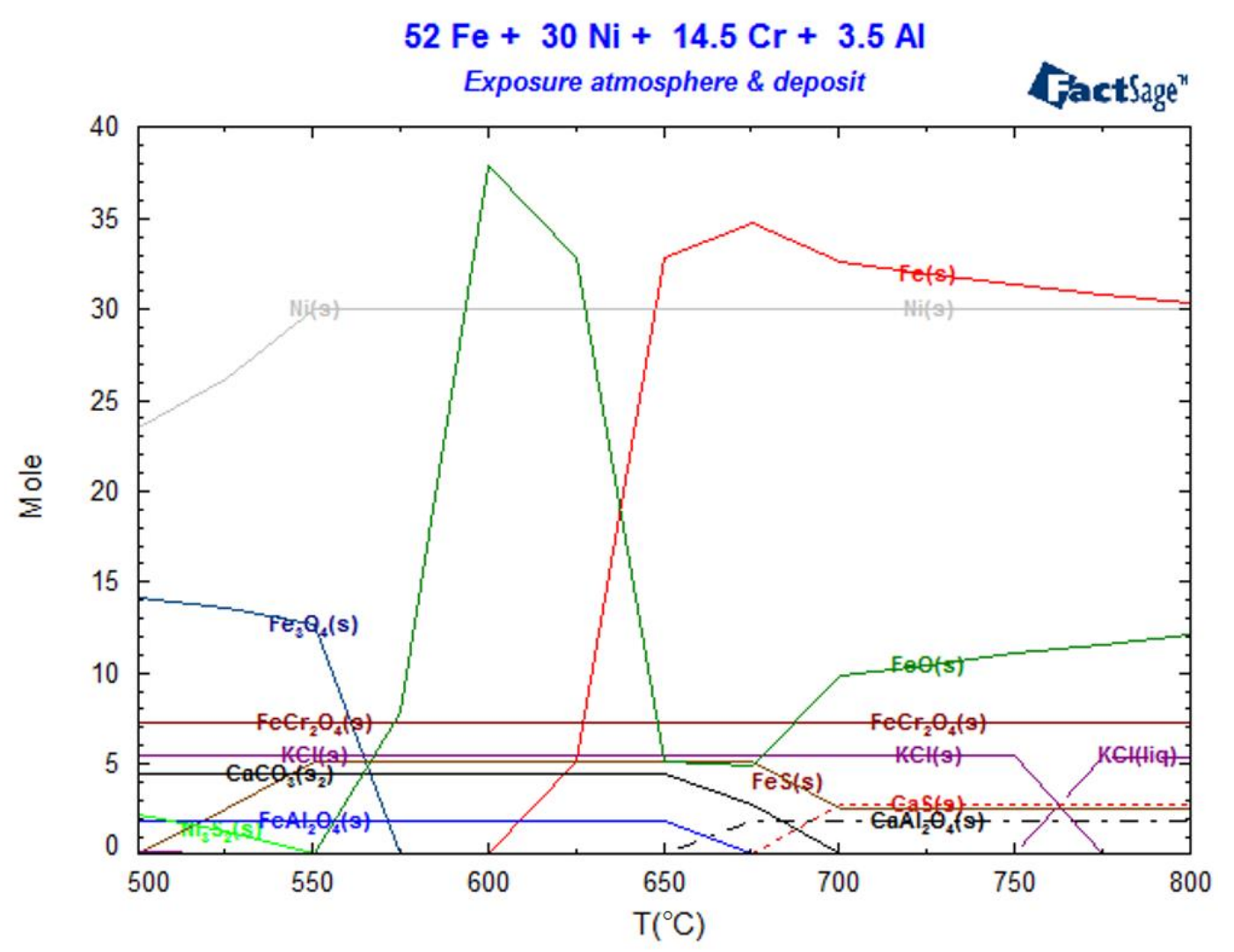

Figure 2. Thermodynamic equilibrium of the selected test material in the test exposure atmosphere, and deposit as a function of temperature.

Powder of the selected composition was prepared by a Hermiga 75/5VI high-pressure gas atomizer. The atomizer was a $5 \mathrm{~kg}$ batch atomizer with induction melting. Argon was used as atomization gas providing an oxygen level of below $1 \mathrm{ppm}$. The used atomization gas pressure was $5 \mathrm{MPa}$ and the overpressure in the melt chamber was $0.025 \mathrm{MPa}$. The melting point of the alloy is around $1450{ }^{\circ} \mathrm{C}$ and the melt temperature was $1650{ }^{\circ} \mathrm{C}$. The FeNiCrAl metal alloy was pre-alloyed to ensure homogenous composition. Chamber fraction of the atomized powder was sieved with $45 \mu \mathrm{m}$ aperture. Undercut was used in thermal spraying and overcut $(45-125 \mu \mathrm{m})$ in HIP. Cyclone fraction was not used as it was considered too fine.

Thermal spray with an HVOF torch was used for depositing coatings of the manufactured powder on X20CrMoV121 ferritic stainless steel cylinders with prior degreasing and grit blasting. In addition, nitrogen permeability test buttons and plates for cross sectioning were coated. The test buttons for nitrogen permeability are porous discs that allow gas to freely flow though, but dense enough to be coated without issues [17]. The used torch was DJ Hybrid (Diamond Jet Hybrid) and the $-45 \mu \mathrm{m}$ sieved chamber fraction was used as the powder. Table 1 presents the used spray parameters.

Table 1. Coating parameters for HVOF spray of the FeNiCrAl powder.

\begin{tabular}{cccccccc}
\hline Torch & Nozzle & Stand Off & Air & Propane & $\mathbf{O}_{2}$ & $\mathbf{N}_{\mathbf{2}}$ & Powder Feed \\
\hline DJ & 2701 & $230 \mathrm{~mm}$ & $400 \mathrm{~L} / \mathrm{min}$ & $62.4 \mathrm{~L} / \mathrm{min}$ & $290 \mathrm{~L} / \mathrm{min}$ & $12.5 \mathrm{~L} / \mathrm{min}$ & $50 \mathrm{~g} / \mathrm{min}$ \\
\hline
\end{tabular}


Hot isostatic pressing was performed using an Asea Mini Hipper QUINTUS Hot Isostatic Press type QIH-9. The overcut of the chamber fraction of the gas atomized powder was packed in an AISI 316L HIP capsule of $\varnothing 27 / 30 \mathrm{~mm} \times 100 \mathrm{~mm}$ using mechanical pressing. The evacuation of the capsule was $24 \mathrm{~h}$ at room temperature down to a pressure level of $10^{-5}$ mbar. Used HIP parameters were $1150{ }^{\circ} \mathrm{C} / 3 \mathrm{~h} / 1000$ bar.

High temperature corrosion testing in oxy-fuel combustion conditions was carried out at VTT in a laboratory scale under isothermal conditions at temperatures of 650 and $720{ }^{\circ} \mathrm{C}$ up to $1000 \mathrm{~h}$ using a furnace system schematically illustrated in Figure 3. The furnace consisted of a horizontal ceramic lined reaction tube and mass flow control systems to produce the targeted gas mixtures. The carrier gas mixture was passed through a humidifying unit containing deionized water before the furnace, to add moisture to the gas mixture. For preheating purposes the gas line goes through the length of the furnace tube before releasing the gas mixture at the other end. The used premixed gas composition was $44 \% \mathrm{CO}_{2}-30 \%$ $\mathrm{H}_{2} \mathrm{O}-0.6 \% \mathrm{SO}_{2}-0.2 \% \mathrm{HCl}-\mathrm{N}_{2}$. During the exposure the specimens were embedded on a $\mathrm{CaSO}_{4}-0.55$ wt $\%$ $\mathrm{KCl}$ deposit. Due to space limitations, only one specimen of each type was exposed.

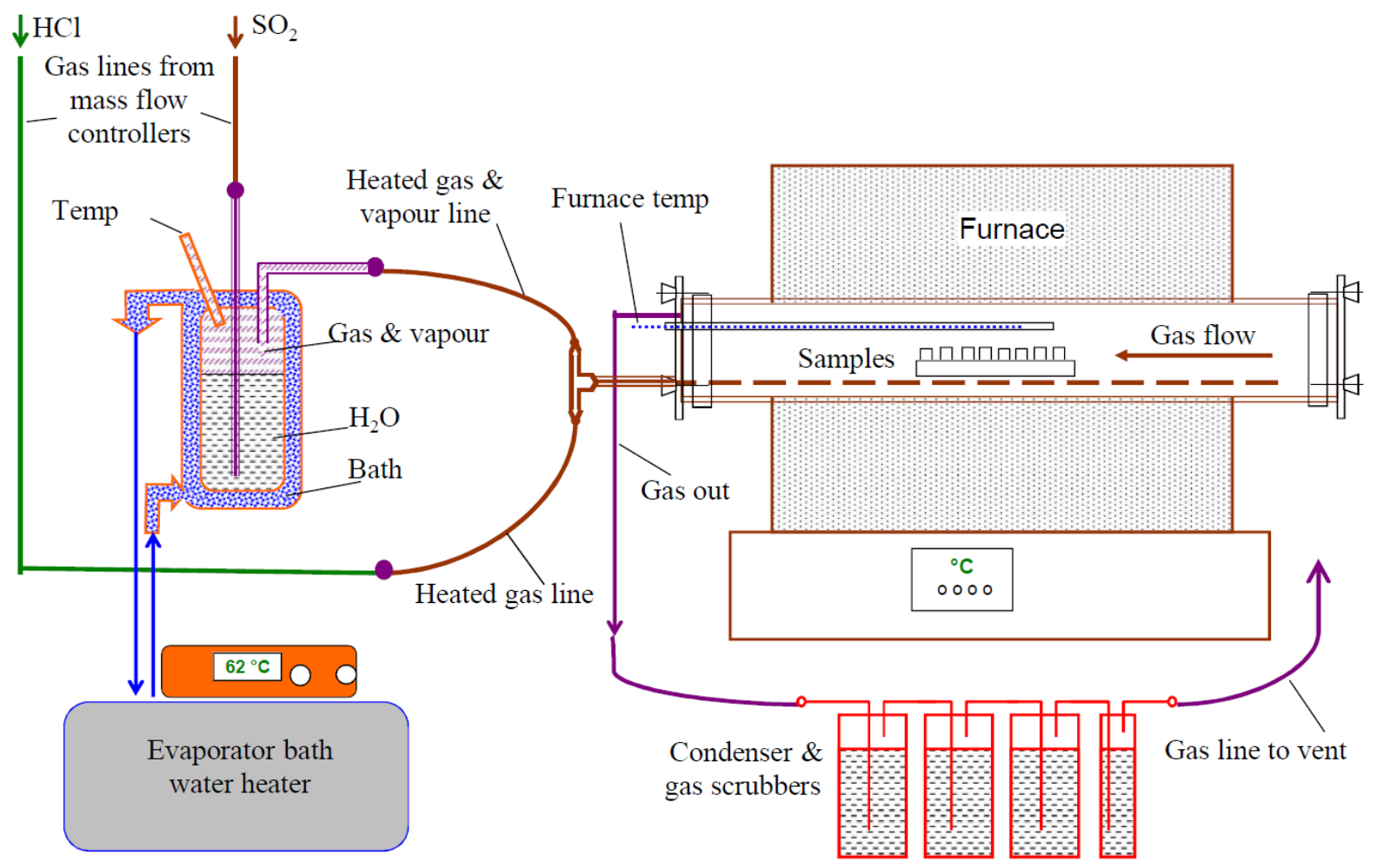

Figure 3. Schematic figure of the high temperature corrosion test system.

The coated specimen was in the shape of a cylinder with $15 \mathrm{~mm}$ diameter and $20 \mathrm{~mm}$ length and the surface was left as coated. The HIP'ed specimens were machined from $15 \mathrm{~mm}$ diameter bars to a disc shape with $15 \mathrm{~mm}$ diameter and $5 \mathrm{~mm}$ height and ground to 600 grit surface finish. Sanicro 25 (UNS S31035) and TP347HFG (UNS S34710) specimens with dimensions of $15 \mathrm{~mm} \times 15 \mathrm{~mm} \times 3 \mathrm{~mm}$ machined from thick walled tubes were used as reference specimens with the surfaces ground to 600 grit finish. Table 2 shows the chemical composition of the reference materials.

After the exposure in the simulated oxy-fuel combustion, metallographic cross-sections were prepared by cutting the samples, mounting them into resin and grinding and polishing with ethanol. 
Characterization was performed with an optical microscope and a FEI XL30 ESEM scanning electron microscope (SEM) equipped with a Thermo Fisher Scientific UltraDry energy dispersive X-ray detector (EDX). X-ray Diffraction (XRD) was performed on corrosion products of the coatings after exposure in the highest temperature. The aim of the materials performance assessment was to characterize the morphologies produced during the exposure testing and to determine the extent of metal damage caused to each specimen during the exposure.

Table 2. Chemical composition of bulk materials Sanicro 25 and TP347HFG by optical emission spectroscopy (OES).

\begin{tabular}{ccccccc}
\hline Alloy & $\mathbf{C r}$ & $\mathbf{N i}$ & $\mathbf{M o}$ & $\mathbf{N b}$ & $\mathbf{F e}$ & Other \\
\hline TP347HFG & 18.3 & 11.7 & 0.23 & 0.92 & bal. & $1.64 \mathrm{Mn}, 0.33 \mathrm{Cu}, 0.4 \mathrm{Si}, 0.07 \mathrm{C}$ \\
Sanicro 25 & 22.3 & 24.9 & - & 0.5 & bal. & $3.4 \mathrm{~W}, 1.5 \mathrm{Co}, 2.9 \mathrm{Cu}, 0.2 \mathrm{Si}, 0.3 \mathrm{Mn}, 0.24 \mathrm{~N}, 0.06 \mathrm{C}$ \\
\hline
\end{tabular}

\section{Results}

\subsection{Powder Manufacturing and Consolidation}

Particle sizes of the manufactured powder were measured using Malvern Mastersizer 3000. The $-45 \mu \mathrm{m}$ sieved powder had D10 15.1, D50 27.4 and D90 $45.3 \mu \mathrm{m}$ values and the $45-125 \mu \mathrm{m}$ sieved powder had D10 34.7, D50 61.3 and D90 $105 \mu \mathrm{m}$ values. The coarser powder contained some fine particles below $45 \mu \mathrm{m}$ although sieved with $45 \mu \mathrm{m}$ sieve. This was because of clogging of the sieve and perhaps too short a sieving time.

SEM images of the powders are presented in Figures 4 and 5. They show some small satellite particles stuck on the surface of larger particles, but the amount of the satellites was so small that it was considered not to affect thermal spraying or HIP. Large magnification images (Figures $4 \mathrm{~b}$ and $5 \mathrm{~b}$ ) show grain structures. The grain structure is larger in large particles than in small particles due to faster cooling rate of the small particles. The grain structure cannot be detected on particles of less than $10 \mu \mathrm{m}$ in diameter. EDX analysis of the composition of the powder is presented in Table 3.

An optical micrograph of the resulting microstructure of the HIP'ed alloy is presented in Figure 6. Coating microstructure on the cross-sectioning plate is shown in Figure 7. Coating thickness on the cylinders varied between 300 and $400 \mu \mathrm{m}$ based on electromagnetic measurements (Elcometer). Porosity was measured by image analysis from several optical micrographs, and the porosity value was $0.31 \%$ in the coating and $1.61 \%$ in the HIP specimen. Nitrogen gas permeability was measured up to 7 bar using Kermetico GPT-02 testing rig and the results show that the coating was gas tight at the tested $270 \mu \mathrm{m}$ thickness. This is in line with the low porosity value. The HIP specimen was not suitable to gas permeability testing, because it had too small diameter for the testing chamber. Coating hardness was tested with an instrumented indenter Zwick ZHU 0.2 using $0.3 \mathrm{~kg}$ load and performing six indents. The measured hardness was 361 HV0.3 with standard deviation of 40 HV0.3. Elastic modulus was calculated using the Oliver and Pharr method and the result was $160 \mathrm{MPa}$ with standard deviation of $10 \mathrm{MPa}$. The considerable amount of standard deviation in the measurements is to be expected due to the varying microstructure. Table 4 summarizes the results. 

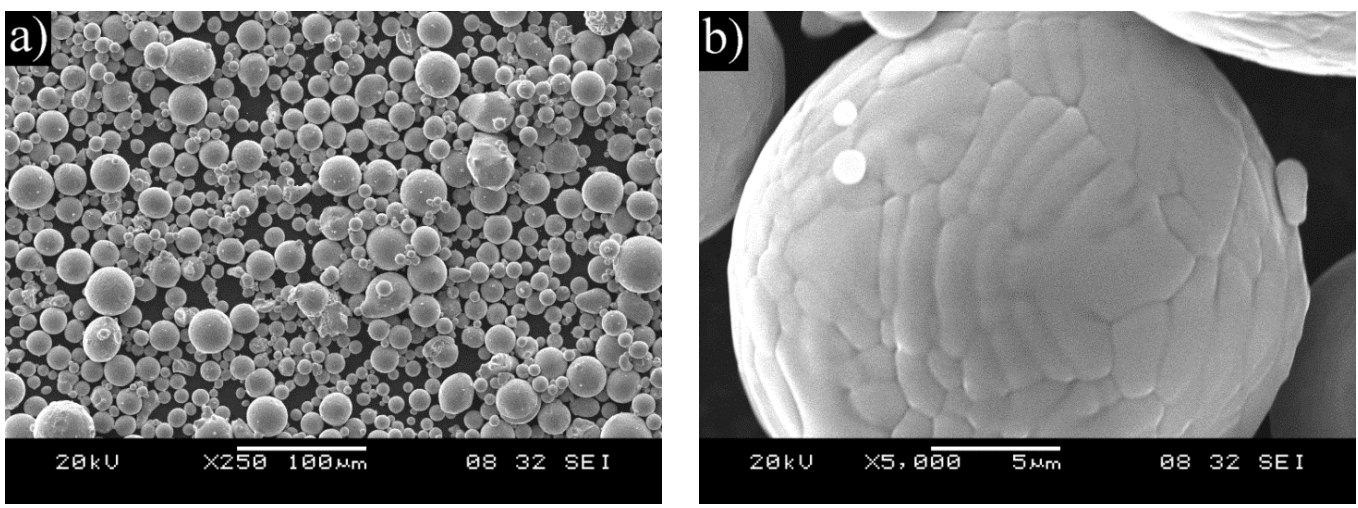

Figure 4. SEM images of gas atomized $\mathrm{FeNiCrAl}$ powder sieved below $45 \mu \mathrm{m}$, magnifications with micron bars. (a) $100 \mu \mathrm{m}$; (b) $5 \mu \mathrm{m}$.
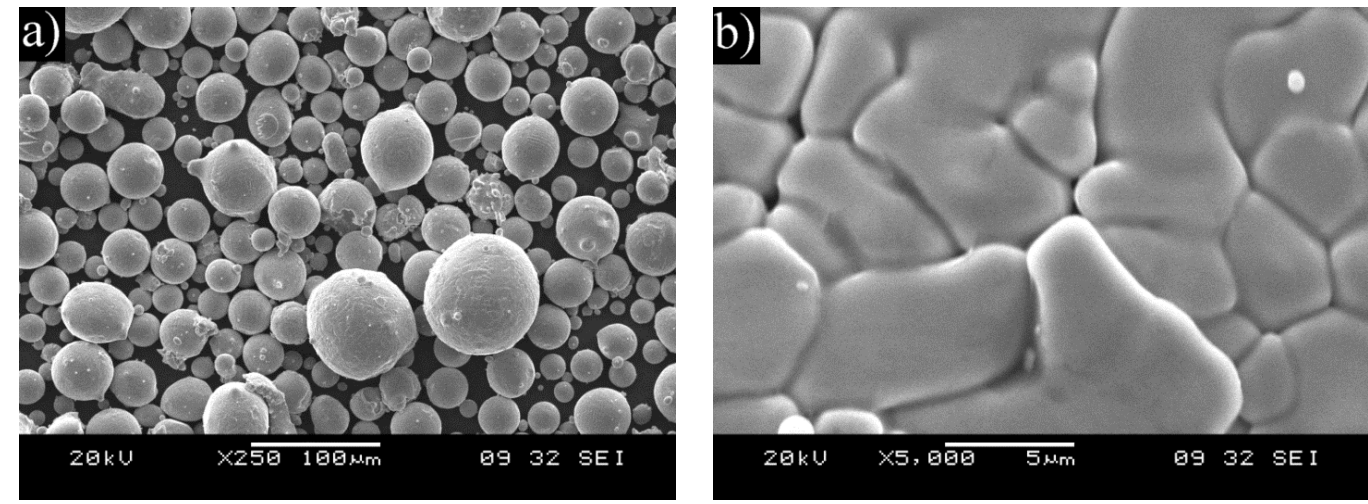

Figure 5. SEM images of gas atomized FeNiCrAl powder sieved 45-125 $\mu$ m, magnifications with micron bars. (a) $100 \mu \mathrm{m}$; (b) $5 \mu \mathrm{m}$.

Table 3. EDX analysis of the FeNiCrAl powder in wt $\%$ and calculated difference in $\%$.

\begin{tabular}{ccccc}
\hline & Fe & Ni & Cr & Al \\
\hline Target & Bal & 30.0 & 14.5 & 3.5 \\
EDX analysis & Bal & 24.8 & 13.5 & 3.5 \\
Difference (\%) & - & -17.3 & -6.9 & 0.0 \\
\hline
\end{tabular}

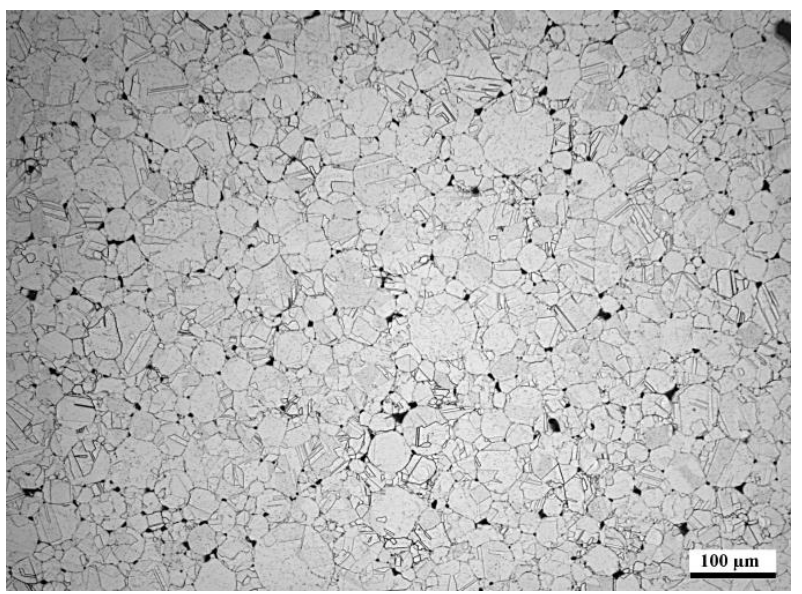

Figure 6. Microstructure of the HIP'ed FeNiCrAl alloy before testing. 


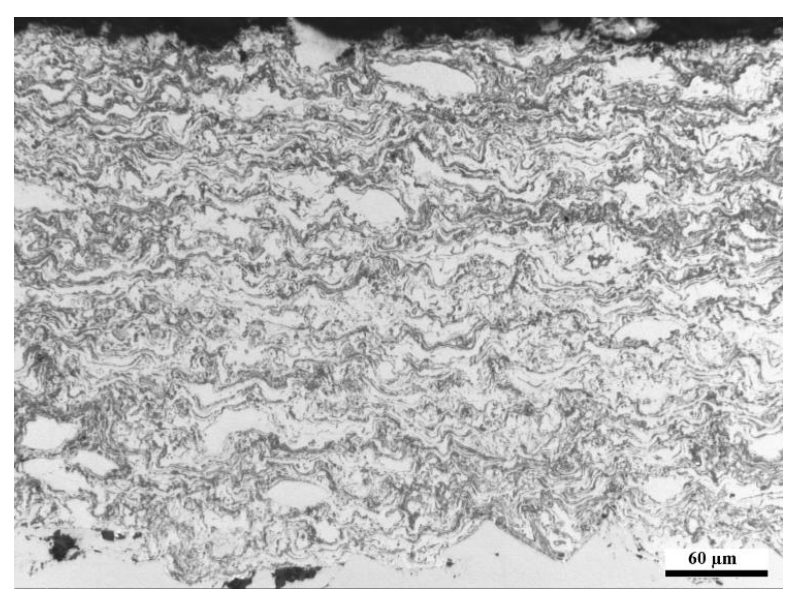

Figure 7. Optical micrograph of a cross-section of HVOF DJ Hybrid sprayed FeNiCrAl coating before testing.

Table 4. Indentation results for the HVOF thermal spray coating.

\begin{tabular}{cccccc}
\hline Coating Method & Hardness (HV0.3) & STDEV & $\boldsymbol{E}$ (Mpa) & STDEV & $\boldsymbol{n}$ \\
\hline DJ Hybrid & 361 & 40 & 160 & 10 & 6 \\
\hline
\end{tabular}

\subsection{Exposure at $650{ }^{\circ} \mathrm{C}$}

The DJ Hybrid sprayed FeCrNiAl coating had protected the X20 stainless steel substrate material during the $700 \mathrm{~h}$ exposure at $650{ }^{\circ} \mathrm{C}$ (Figure 8). Thick salt deposits had stuck on the coated specimen. Average outer corrosion product thickness on the deposit side was measured from the cross section to be $60 \mu \mathrm{m}$. The measurements were complicated by some corrosion products that had diffused into the deposits. In addition, there was $20 \mu \mathrm{m}$ of internal corrosion in the coating.

Bulk reference materials were exposed for $1000 \mathrm{~h}$. During the exposure, TP347HFG steel had formed a $100 \mu \mathrm{m}$ thick corrosion product layer plus $30 \mu \mathrm{m}$ of internal corrosion through grain boundaries. Sanicro 25 steel had formed a 200 to $500 \mu \mathrm{m}$ thick corrosion layer and 20 to $50 \mu \mathrm{m}$ of internal corrosion through grain boundaries. EDX analysis revealed sulfur in the grain boundaries. Table 5 summarizes all the corrosion layer thicknesses at $650{ }^{\circ} \mathrm{C}$.

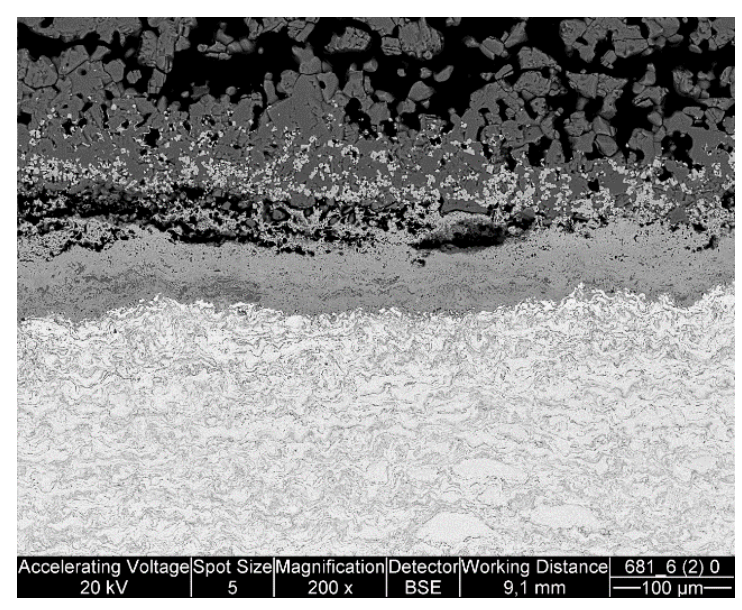

Figure 8. SEM image of the HVOF DJ Hybrid sprayed FeNiCrAl coating cross-section after the exposure at $650{ }^{\circ} \mathrm{C}$ for $700 \mathrm{~h}$. 
Table 5. Corrosion layer thicknesses in $\mu \mathrm{m}$ at $650{ }^{\circ} \mathrm{C}$. HIP sample was not exposed at this temperature. The HVOF coating was exposed for $700 \mathrm{~h}$ while the others were exposed for $1000 \mathrm{~h}$.

\begin{tabular}{cccc}
\hline Layer & HVOF (DJ) & TP347HFG & Sanicro 25 \\
\hline Outer layer(s) & 60 & 100 & $200-500$ \\
Internal & 20 & 30 & $20-50$ \\
\hline
\end{tabular}

\subsection{Exposure at $720^{\circ} \mathrm{C}$}

At $720^{\circ} \mathrm{C}$, an average corrosion product layer thickness of $240 \mu \mathrm{m}$ was measured for the DJ Hybrid sprayed coating. However, there was sulfur penetration through the coating all the way to the substrate, $250 \mu \mathrm{m}$ below the remaining coating surface (Figure 9). Figure $9 \mathrm{~b}$ shows that the sulfur content is highest at the corrosion front and approximately $100 \mu \mathrm{m}$ inwards to the coating. $\mathrm{Cr}$ and $\mathrm{O}$ can be found above the corrosion front as a thick and porous layer. Below the layer the coating depleted of $\mathrm{Cr}$, although there is some left. XRD analysis performed on the corrosion products of the coating revealed $\mathrm{Fe}_{2} \mathrm{O}_{3}$, $\mathrm{FeS}_{2}, \mathrm{FeCr}_{2} \mathrm{O}_{4}$.
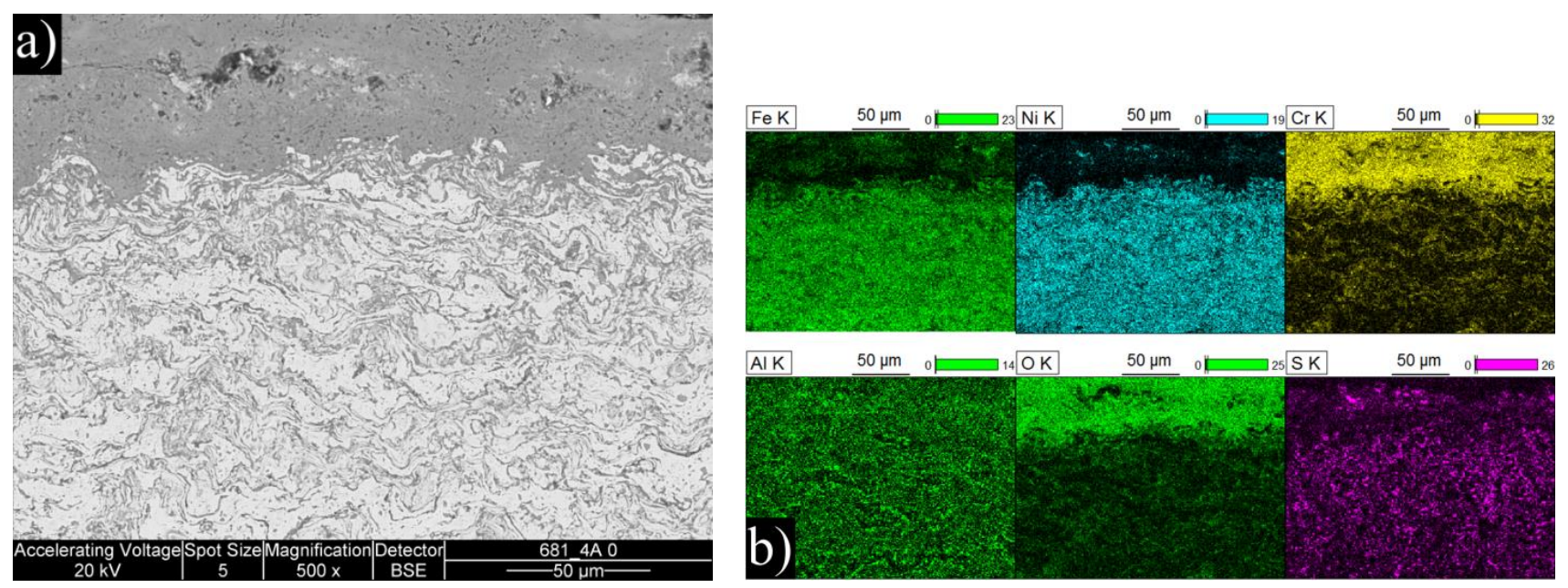

Figure 9. (a) SEM image of a cross-section of the HVOF DJ sprayed FeNiCrAl coating after the exposure at $720{ }^{\circ} \mathrm{C}$ for $700 \mathrm{~h}$; (b) EDS elemental maps of the area shown in (a).

HIP'ed specimen exposed at $720{ }^{\circ} \mathrm{C}$ for $1000 \mathrm{~h}$ had corrosion products partially spalled off. There was from 30 to $50 \mu \mathrm{m}$ of continuous corrosion layer left on the surface and internal corrosion from $50 \mu \mathrm{m}$ up to a depth of $170 \mu \mathrm{m}$ (Figure 10). The internal corrosion had first progressed through particle boundaries, some of which had clear gaps, and then through grain boundaries inside the particles (Figure 11a). EDX map (Figure 11b) shows that $\mathrm{Cr}$ was removed from particle boundaries where the corrosion progressed. Al was enriched at the particle boundaries and on top of the area where individual particles can still be distinguished. A Cr-rich layer was formed above the Al-rich layer. 


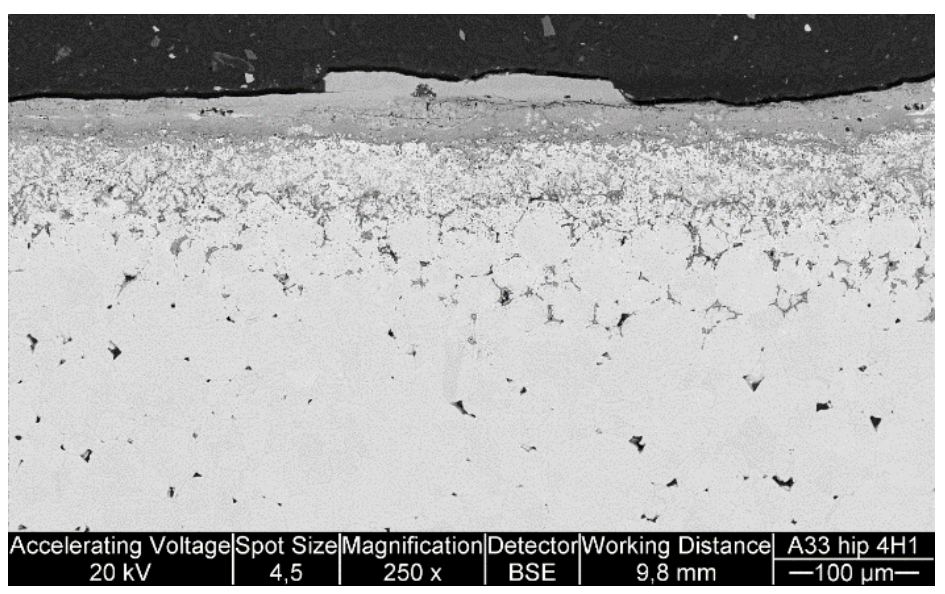

Figure 10. SEM image of $\mathrm{HIP}(\mathrm{FeNiCrAl})$ cross-section.
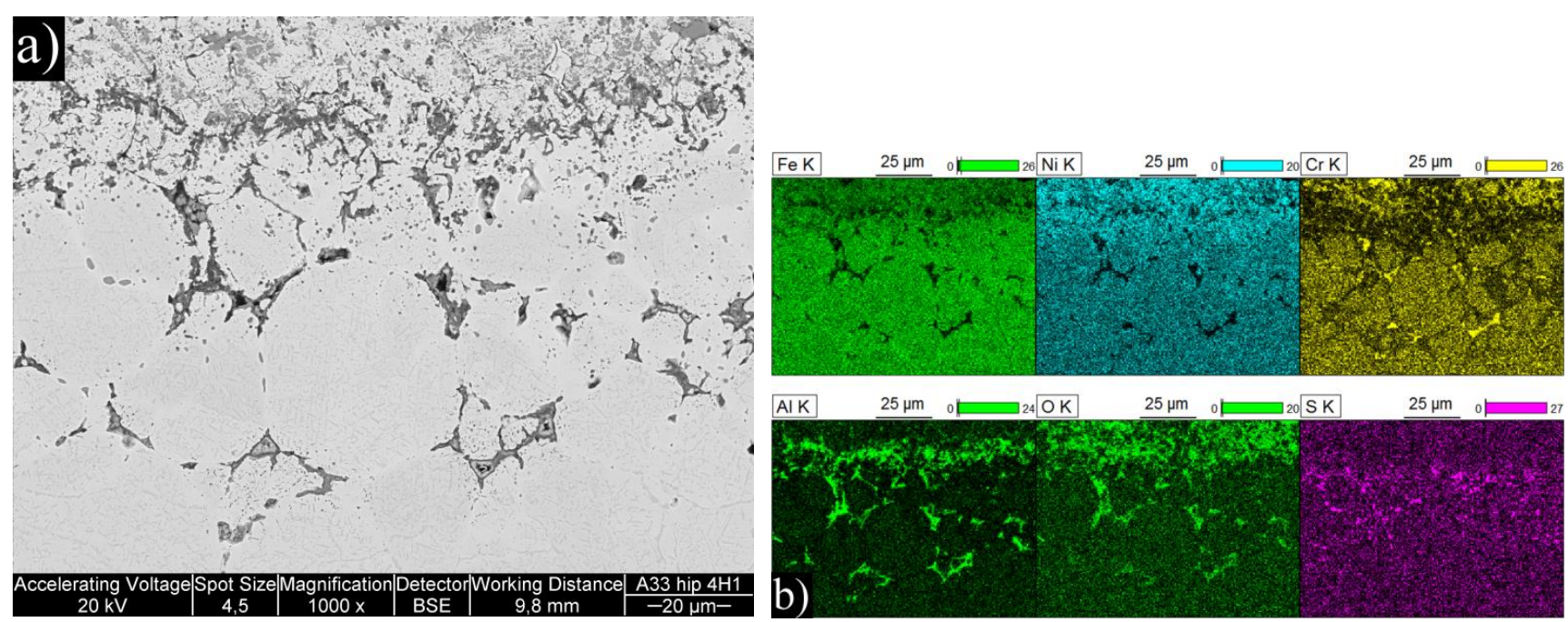

Figure 11. (a) SEM image of HIP (FeNiCrAl) cross-section near the surface after the exposure at $720{ }^{\circ} \mathrm{C}$ for $700 \mathrm{~h}$; (b) EDX elemental map of the same area.

The bulk reference material TP347HFG had corrosion layer thickness of $100 \mu \mathrm{m}$ on the surface after the $1000 \mathrm{~h}$ exposure at $720{ }^{\circ} \mathrm{C}$ (Figure 12). However, the outer layer of the oxide was detached. In addition, there was up to $100 \mu \mathrm{m}$ of internal degradation. EDX analyses showed sulfur penetration through grain boundaries. Small and isolated $\mathrm{Ni}$ and $\mathrm{Nb}$ rich areas can still be observed within the oxide layer along with $\mathrm{S}$ at matching locations. Sanicro 25 (Figure 13) had $300 \mu \mathrm{m}$ of corrosion products on the surface. However, some spallation had also occurred in this case. Internal corrosion for Sanicro 25 ranged from 300 to $500 \mu \mathrm{m}$. The corrosion front appears to be depleted of $\mathrm{Cr}$, while $\mathrm{Ni}$ is enriched (Figure 13b). S and $\mathrm{Cl}$ traces were found at grain boundaries, which were the main route for corrosion. Table 6 summarizes all the corrosion layer thicknesses at $720{ }^{\circ} \mathrm{C}$. 

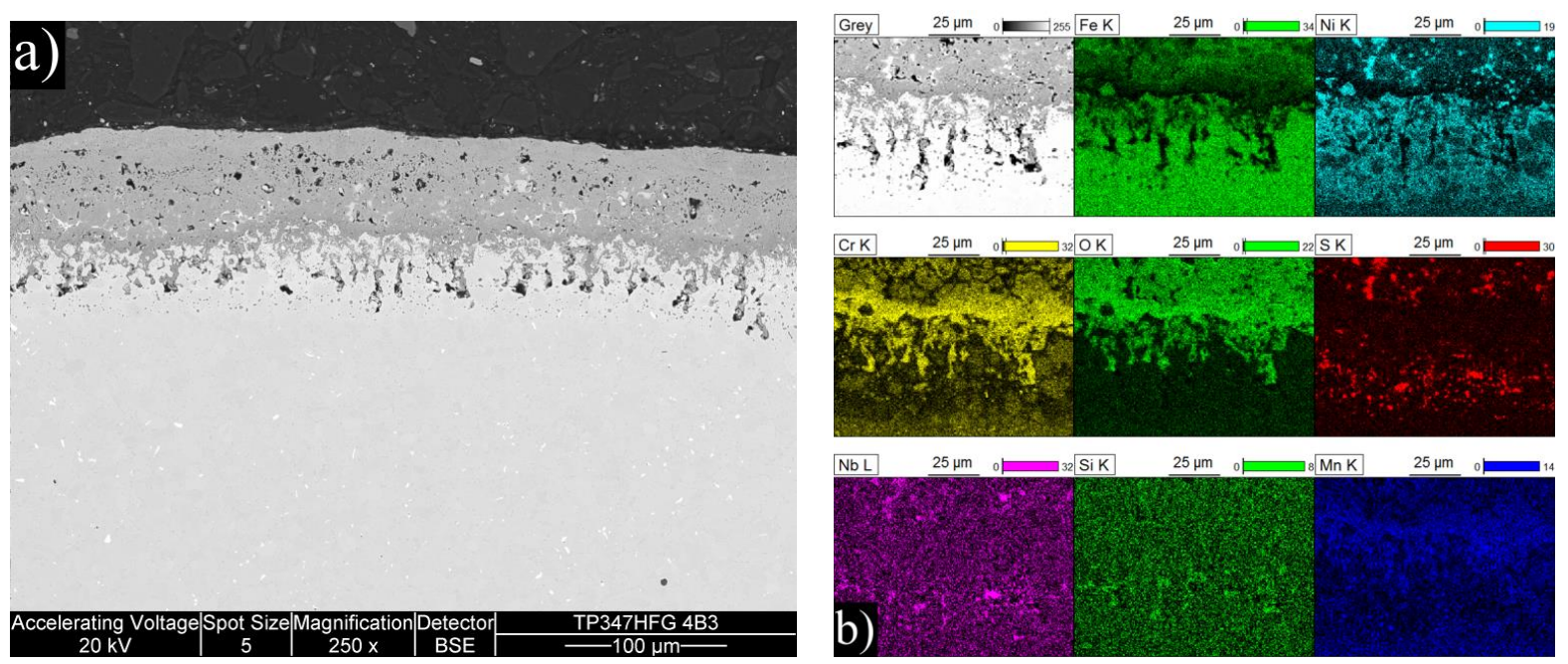

Figure 12. (a) SEM image of TP347HFG steel cross-section near the surface after the exposure at $720{ }^{\circ} \mathrm{C}$ for $1000 \mathrm{~h}$; (b) EDX elemental map of the corrosion front at a higher magnification.
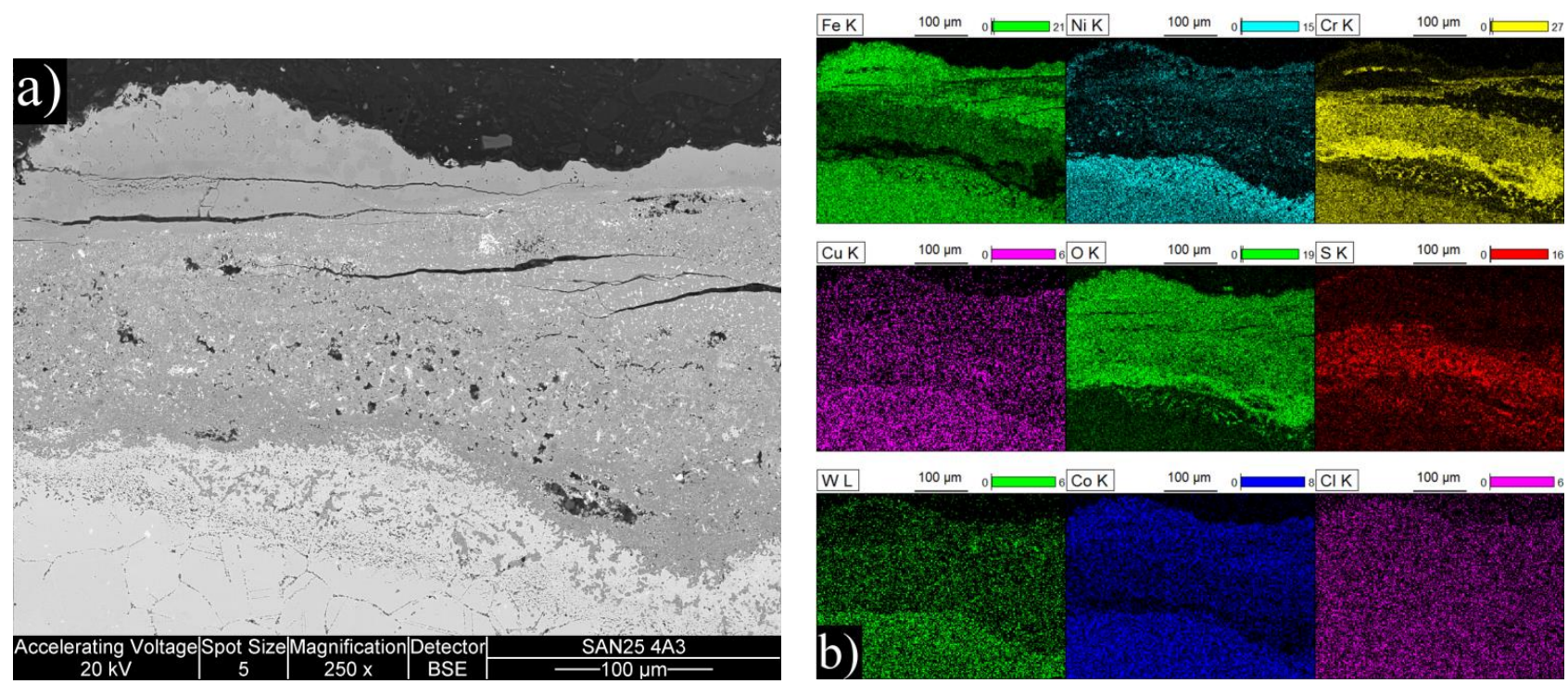

Figure 13. (a) SEM image of Sanicro 25 steel cross-section near the surface after the exposure at $720{ }^{\circ} \mathrm{C}$ for $1000 \mathrm{~h}$; (b) EDX elemental map of the same area.

Table 6. Corrosion layer thicknesses in $\mu \mathrm{m}$ at $720^{\circ} \mathrm{C}$. Some of the external corrosion layers had spalled off, indicated by the "+" signs. The HVOF coating was exposed for $700 \mathrm{~h}$ while the others were exposed for $1000 \mathrm{~h}$.

\begin{tabular}{ccccc}
\hline Layer & HVOF (DJ) & HIP & TP347HFG & Sanicro 25 \\
\hline Outer layer(s) & 240 & $50+$ & $100+$ & $300+$ \\
Internal & 250 & $50-170$ & 100 & $300-500$ \\
\hline
\end{tabular}




\section{Discussion}

As expected, the results showed that a higher temperature yielded higher amounts of corrosion. The corrosion mechanism appeared to be the same in both temperatures: sulfidation, possibly preceded by chlorine corrosion. The formation of such types of corrosion products cause by chlorine corrosion have also been reported by Oksa et al. [17]. Alkali chlorides in deposits may cause accelerated corrosion well below the melting point of $\mathrm{KCl}$ [18]. Gases containing $\mathrm{HCl}$ for example, can influence the corrosion caused by other mechanisms, such as sulfidation, by breaking down the protective oxides and allowing corrosive species to reach the metal surface [18]. Similar results have been reported by Haanappel et al. [19], who found that $\mathrm{HCl}$ in an oxidizing-sulfidizing environment increased the corrosion rate significantly and made the scales thick, porous and non-protective, comparable to the results of this study.

The manufactured FeNiCrAl composition was both thermal sprayed and HIP'ed so that the effect of microstructure to the performance could be seen. The structure of the DJ Hybrid coating showed some large splats, which were nicely deformed, and some completely oxidized small particles. The coating could have been improved by using a tighter powder fraction, either by removing the smallest particles and using current spray parameters, or by removing the largest particles and using cooler spray parameters. The over-oxidized lamellae boundaries in the coating could have contained porosity or might have micro-cracked under thermal stress and therefore allow faster diffusion of corrosive species into the coating and enabled diffusion of coating element outward, as $\mathrm{Ni}$ and Fe were found diffused deep into the deposits. Having small lamellas lead to an increased amount of lamellae boundaries and hence higher diffusion when the boundaries act as diffusion paths. Aluminum did not effectively block the lamellae boundaries, and XRD results showed that the predicted phases did not form. This was likely due to the composition mismatch between the calculated and manufactured powder. Based on the EDX results of Table 3, there is room for optimization in the powder manufacturing, because the actual composition had $17 \%$ less $\mathrm{Ni}$ and $7 \%$ less $\mathrm{Cr}$ than planned. Al content was exactly as planned. Unfortunately, the HIP'ed specimen had large porosity between the particles, making it more difficult to compare with the other specimens as intended. However, the larger particles do show how the corrosive species diffused inside the particles through grain boundaries. The same was observed on a smaller scale in the coatings.

The exposure tests were conducted on single specimens, so the approach is guiding rather than statistical. TP347HFG performed well at $650{ }^{\circ} \mathrm{C}$ by having the second thinnest corrosion products $(100+30 \mu \mathrm{m})$, being only slightly behind the HVOF coating, which would have had $86+29 \mu \mathrm{m}$ if we assume linear growth from $700 \mathrm{~h}$ exposure to $1000 \mathrm{~h}$. At $720^{\circ} \mathrm{C}$ the oxide had spalled, but based on the amount of internal corrosion, the material could be the best performer of the experiment. The reference material Sanicro 25 had disastrous performance at both temperatures, even though it contained more $\mathrm{Cr}$ (22.5 vs. 18 wt \%) and Ni (25 vs. 11 wt \%) than the TP347HFG. Selective corrosion of Cr has been observed to increase in $\mathrm{Cl}$ containing atmospheres when $\mathrm{Cr}$ content increases [20]. However, the $\mathrm{Cr}$ difference of TP347HFG and Sanicro 25 is quite small compared to the performance difference. Therefore, the very poor performance of Sanicro 25 steel was more likely related to its $\mathrm{Cu}$ content.

When present in deposits, copper has been found to increase corrosion rates significantly in chlorine containing conditions by catalyzing the formation of elemental chlorine from $\mathrm{HCl}[21,22]$. Because chemical composition of Sanicro 25 with higher $\mathrm{Cr}$ and Ni content would suggest that the material had 
better corrosion resistance than TP347HFG, we suggest that copper has probably had an influence on the high corrosion rate as an alloying element. Together with preferential removal of $\mathrm{Cr}$ at the corrosion front, copper may have reacted with chlorine and contributed to the very high corrosion rate of Sanicro 25. As a reference, TP347HFG and SAN25 have been tested in air- and oxy-firing conditions by Holcomb et al. [13]. The corrosion rates varied from $0-25 \mathrm{~nm} / \mathrm{h}$ at $550{ }^{\circ} \mathrm{C}$ to $210-615 \mathrm{~nm} / \mathrm{h}$ at corrosion peak temperature of about $700{ }^{\circ} \mathrm{C}$, when chlorine was not present in the deposit.

\section{Conclusions}

This study presented material development from thermodynamic calculations of suitable composition to performance in a simulated oxy-fuel combustion environment. In between, there were steps for creating the desired composition in the form of a powder, and using two different consolidation methods to produce coating or bulk material from the powder. HVOF (DJ) coating had better performance than the reference materials at $650{ }^{\circ} \mathrm{C}$. However, at $720{ }^{\circ} \mathrm{C}$ there was significant amount of sulfur penetration throughout the coating. The HIP'ed structure was hard to compare due to its porosity. Overall the best material in these experiments was the TP347HFG steel. In light of these results, the execution of the development chain has room for improvement and further research is required.

\section{Acknowledgments}

The authors would like to thank VTT Technical Research Centre of Finland Ltd. for the financial support.

\section{Author Contributions}

Maria Oksa and Satu Tuurna designed the research. Juha Lagerbom, Jouko Virta and Tomi Suhonen performed and designed the experimental work. Sanni Yli-Olli performed the thermodynamic calculation. Jarkko Metsäjok performed the SEM analysis and authored the manuscript, and Maria Oksa, Satu Tuurna, Juha Lagerbom and Jouko Virta co-authored the work.

\section{Conflicts of Interest}

The authors declare no conflict of interest.

\section{References}

1. International Energy Agency. World Energy Outlook Special Report 2015: Energy and Climate Change; International Energy Agency: Paris, France, 2015; Available online: http://www.iea.org/ publications/freepublications/publication/WEO2015SpecialReportonEnergyandClimateChange.pdf (accessed on 3 September 2015).

2. Zheng, L. Oxy-Fuel Combustion for Power Generation and Carbon Dioxide $\left(\mathrm{CO}_{2}\right)$ Capture; Woodhead Publishing: Cambridge, UK, 2011; p. 374.

3. Bordenet, B. Influence of novel cycle concepts on the high-temperature corrosion of power plants. Mater. Corros. 2008, 59, 361-366. 
4. Scheffknecht, G.; Al-Makhadmeh, L.; Schnell, U.; Maier, J. Oxy-fuel coal combustion-A review of the current state-of-the-art. Int. J. Greenh. Gas Control 2011, 5, S16-S35.

5. Kranzmann, A.; Neddemeyer, T.; Ruhl, A.S.; Huenert, D.; Bettge, D.; Oder, G.; Saliwan-Neumann, R. The challenge in understanding the corrosion mechanisms under oxyfuel combustion conditions. Int. J. Greenh. Gas Control 2011, 5, S168-S178.

6. Stein-Brzozowska, G.; Maier, J.; Scheffknecht, G. Impact of the oxy-fuel combustion on the corrosion behaviour of advanced austenitic superheater materials. Energy Procedia 2011, 4, 2035-2042.

7. Pint, B.A.; Thomson, J.K. Effect of oxy-firing on corrosion rates at $600-650{ }^{\circ}$ C. Mater. Corros. 2014, 65, 132-140.

8. Covino, B.S., Jr.; Matthes, S.A.; Bullard, S.J. Effect of Oxyfuel Combustion on Superheater Corrosion. In Proceedings of the NACE CORROSION 2008 Conference \& Expo, New Orleans, LA, USA, 16-19 March 2008; p. 8456.

9. Montgomery, M.; Bjurman, M.; Hjørnhede, A.; Rombrecht, H.B.; Lisk, A.; Krautz, H.J. High temperature corrosion investigation in an oxyfuel combustion test rig. Mater. Corros. 2015, 66, 257-269.

10. Yu, D.; Morris, W.J.; Erickson, R.; Wendt, J.O.L.; Fry, A.; Senior, C.L. Ash and deposit formation from oxy-coal combustion in a $100 \mathrm{~kW}$ test furnace. Int. J. Greenh. Gas Control 2011, 5, S159-S167.

11. Gagliano, M.S.; Hack, H.; Stanko, G. Update on the fireside corrosion resistance of proposed advanced ultrasupercritical superheater and reheater materials: Laboratory and field test results. In Proceedings of the Clearwater Coal Conference 34th International Technical Conference on Coal Utilization \& Fuel Systems, Clearwater, FL, USA, 31 May-4 June 2009.

12. Syed, A.U.; Simms, N.J.; Oakey, J.E. Fireside corrosion of superheaters: Effects of air and oxy-firing of coal and biomass. Fuel 2012, 101, 62-73.

13. Holcomb, G.R.; McGhee, B.F.; Fry, A.T.; Simms, N.J.; Davis, K. Boiler corrosion and monitoring. Mater. High Temp. 2013, 30, 271-286.

14. Hussain, T.; Syed, A.Y.; Simms, N.J. Trends in fireside corrosion damage to superheaters in air and oxy-firing of coal/biomass. Fuel 2013, 113, 787-797.

15. Huczkowski, P.; Olszewski, T.; Schiek, M.; Lutz, B.; Holcomb, G.R.; Shemet, V.; Nowak, W.; Meier, G.H.; Singheiser, L.; Quadakkers, W.J. Effect of $\mathrm{SO}_{2}$ on oxidation of metallic materials in $\mathrm{CO}_{2} / \mathrm{H}_{2} \mathrm{O}$-rich gases relevant to oxyfuel environments. Mater. Corros. 2014, 65, 121-131.

16. Bellucci, A.; Bellini, S.; Pileggi, R.; Stocchi, D.; Tuurna, S. Effect of Al Enrichment by Pack Cementation of FeCr Coatings Deposited by HVOF. J. Therm. Spray Technol. 2015, 24, 244-251.

17. Oksa, M.; Metsäjoki, J.; Kärki, J. Thermal spray coatings for high-temperature corrosion protection in biomass co-fired boilers. J. Therm. Spray Technol. 2015, 24, 194-205.

18. Nielsen, H.P.; Frandsen, F.J.; Dam-Johansen, K.; Baxter, L.L. The implications of chlorine-associated corrosion on the operation of biomass-fired boilers. Prog. Energy Combust. Sci. 2000, 26, 283-298.

19. Haanappel, V.A.C.; Haanappel, N.W.J.; Fransen, T.; van Corbach, H.D.; Gellings, P.J. Corrosion Kinetics of Low- and High-Alloy Steels in Chlorine-Containing Gas Atmospheres. Corrosion 1992, $48,812-821$.

20. Montgomery, M.; Karlsson, A. In-situ corrosion investigation at Masned $\varnothing$ CHP plant-A straw-fired power plant. Mater. Corros. 1999, 50, 579-584. 
21. Galetz, M.C.; Bauer, J.T.; Schutze, M.; Noguchi, M.; Takatoh, C.; Cho, H. The Influence of Copper in Ash Deposits on the Corrosion of Boiler Tube Alloys for Waste-to-Energy Plants. Mater. Corros. 2012, 63, 1-8.

22. Oksa, M.; Tuurna, S.; Varis, T. Increased lifetime for biomass and waste to energy power plant boilers with HVOF coatings-High temperature corrosion testing under chlorine-containing molten salt. J. Therm. Spray Technol. 2013, 22, 783-796.

(C) 2015 by the authors; licensee MDPI, Basel, Switzerland. This article is an open access article distributed under the terms and conditions of the Creative Commons Attribution license (http://creativecommons.org/licenses/by/4.0/). 